Full length research article

\section{ADSORPTION EFFICIENCY OF COCONUT SHELL-BASED ACTIVATED CARBONS ON COLOUR OF MOLASSES, OILS, DISSOLVED OXYGEN AND RELATED PARAMETERS FROM INDUSTRIAL EFFLUENT}

\author{
${ }^{*}$ C.E. GIMBA ${ }^{1} \&$ M. TUROTI2 \\ Department of Chemistry \\ ${ }^{1}$ Ahmadu Bello University, \\ Zaria, Nigeria \\ ${ }^{2}$ Federal College of Education, \\ Zaria, Nigeria \\ *(Corresponding author) \\ gimbace@yahoo.com
}

\begin{abstract}
The adsorption efficiency of $\mathrm{FeCl}_{3}, \mathrm{CaCl}_{2}$ and $\mathrm{K}_{2} \mathrm{CO}_{3}$-activated carbon for the $500 \mu \mathrm{m}$ particle size produced from previously carbonized coconut shell on some adsorbates obtained from an industrial effluent and wastewaters as well as the colour of molasses has been studied. The adsorbates include oil and grease, dissolved oxygen (DO); biochemical oxygen demand (BOD) and chemical oxygen demand (COD), dissolved and suspended solids as well as total solids present in an industrial effluent sample. A colour comparator was used to determine the colour of the molassess, volumetric analysis was used to determine oxygen and related parameters while oil and grease were determined by gravimetry. The results showed that the activated carbons used in this study are capable of reducing the level of colour present in molasses and amount of oil/grease from a textile effluent. Ninety two and $97.4 \%$ of molasses and oil/grease respectively can be adsorbed onto $500 \mu \mathrm{m}$ particle size of $\mathrm{ZnCl}_{2}$ - activated carbon at room temperature. Out of the four activated carbons, $\left(\mathrm{FeCl}_{3}-\mathrm{Ac}, \mathrm{CaCl}_{2}-\mathrm{Ac}, \mathrm{ZnCl}_{2}-\mathrm{Ac}\right.$ and $\mathrm{K}_{2} \mathrm{CO}_{3}-\mathrm{Ac}$,) the $\mathrm{FeCl}_{3}-\mathrm{Ac}$ is most effective in adsorbing the dissolved oxygen, chemical oxygen demand, biochemical oxygen demand, dissolved, suspended and total solid present in a sample of a textile effluent. The $\mathrm{FeCl}_{3}-\mathrm{Ac}$ is more effective in adsorbing the solid impurities than the oxygen demands but least effective in adsorbing dissolved oxygen. There is a high correlation coefficient between the oxygen parameters and solids present in the effluent. This shows that the greater the amount of solids in an effluent the more the amount of oxygen required for biochemical and chemical processes. $\mathrm{ZnCl}_{2}$-activated carbon most effectively adsorbed $92.2 \%$ colour of the molasses while the $\mathrm{FeCl}_{3}$-activated was most effective in adsorbing $94.3 \%$ of oil/grease, $46.2 \%$ of dissolved oxygen, $71.9 \%$ of BOD, $72.1 \%$ of COD and $96 \%$ each of dissolved solids (DS), suspended solids (SS) and total solids (TS). The coefficients of correlation found between each of DO, COD or BOD and DS, SS and TS adsorbed were $0.999,0.907$ and 0.763 respectively.
\end{abstract}

Key words: Coconut shell, activated carbon, adsorption, oxygen demand, solids.

\section{INTRODUCTION}

The relative cheapness, availability, high stability high adsorptive capacity and regenerative characteristics due to the finer pore structure of its shell based- activated carbon compared to other raw materials (Houghton \& Wildman 197; Hardman 1992; Mkayula \& Matumbo 1994; Pollard 1995) have made coconut shell excelled in areas of practical applications (Noah 1991). Areas of interest include the use of activated carbon from coconut shell to reduce or eliminate hazardous and objectionable gaseous and liquid components of industrial effluent, its use in adsorption of oil and grease in industrial effluents to ascertain the level of removal by activated carbon and the effect of activated carbons on the colour of molasses obtained from sugar.

Dissolved oxygen is the amount of oxygen found in a sample of an effluent or water waste at the time of collection (Gimba 2001). It determines the level of survival of aquatic organisms and therefore its determination in any effluent discharged into rivers is very important. Biochemical oxygen demand (BOD) measures the quantity of oxygen required by aerobic biochemical (bacterial) action for oxidation of suspended biodegradable matter present in a sample. The quantity of the matter is directly related to the BOD. The Chemical Oxygen Demand (COD) is a measure of the amount of oxygen required for complete oxidation of decomposed organic matter, in a given sample, to carbon (IV) oxide and water. Effluent BOD and COD usually far exceed discharge level permitted by most environmental protection agencies. The determination and reduction of these parameters in an effluent becomes very important (Lyman 1978). Some correlations are expected between the solids (total, suspended or dissolved) and these oxygen parameters. The use of activated carbon from coconut shell in the adsorption of solids present in an effluent sample will also be the focus of this study.

Water pollution by oil and grease arises from spillage or wastes from oil industries or decomposition reactions which emanate from some aquatic organisms. These oils/grease float on top of rivers being insoluble and less dense than water and prevent normal diffusion of oxygen into the water for use of aquatic lives. Therefore the removal or reduction of the oils and grease from industrial effluent before discharge into the rivers becomes imperative. The menace and injury imposed on direct consumers of water in the riverine areas will be reduced if such oil/grease are reduced in the effluents. A study of adsorption of these oils and grease in an industrial effluent to ascertain the level of removal by activated carbon will constitute a dimension of this report.

Molasses from treated and affinated sugar generally have some objectionable colour (Gimba 2001). A section of this report will consider the effect of activated carbons on the colour of molasses obtained from a sugar company in Nigeria aimed at reducing the objectionable colour inherent in this substance and possibly to attract other uses. 


\section{MATERIALS AND METHODS}

The procedure for activation using $\mathrm{FeCl}_{3}, \mathrm{CaCl}_{2}, \mathrm{ZnCl}_{2}$ and $\mathrm{K}_{2} \mathrm{CO}_{3}$ as activating agents has already been described (Gimba 2001). The coconut shells used in this study were collected from the market, home premises and dumps in and around Zaria, Nigeria. The shells were washed with water, dried in oven and then sieved into $500 \mu \mathrm{m}$ particle size. The molasses were obtained from the Nigerian Sugar Company, Bacita, Kwara State, Nigeria. All chemical reagents were of analar grades from Sigma Chemical Company. The effluent was discharged by the Nigerian Textile PIc, Kaduna Nigeria. The standard methods for examination of water and wastewaters (SMEWW 1992) were used to determine the various parameters.

\section{Determination of Amount of Adsorbed Molasses}

Fifty $\mathrm{cm}^{3}$ portion (Hassler 1974) of the molasses solution was measured into a $150 \mathrm{~cm}^{3}$ beaker and $0.20 \mathrm{~g}$ of $\mathrm{FeCl}_{3}$-activated carbon $(\mathrm{Ac})$ added and the mixture stirred until wetted down. The mixture was then boiled using a hot plate. The resultant mixture was filtered through a sintered glass crucible (porosity 4) and the colour of the filtrate measured using Lovibond 1000 comparator in Hazen units. The above procedure was repeated using the other activated carbons i.e. $\mathrm{CaCl}_{2}$-activated carbon, $\mathrm{ZnCl}_{2}$-activated carbon and $\mathrm{K}_{2} \mathrm{CO}_{3}$-activated carbon. The percentage colour removal for the different activated carbons taking the unadsorbed colour as 100 Hazens was determined.

\section{Determination of Total Oil and Grease}

To $360 \mathrm{~cm}^{3}$ of the effluent sample in a graduated $500 \mathrm{~cm}^{3}$ separatory funnel was added $4.0 \mathrm{~cm}^{3}$ of $14.5 \mathrm{M} \mathrm{H}_{2} \mathrm{SO}_{4}$ standard solution. The funnel was stoppered and shaken several times. 20 $\mathrm{cm}^{3}$ of $80 \%$ hexane and $20 \%$ methyl t-butyl ether was added and shaken vigorously for 2 minutes and allowed to stand for 10 minutes. The organic layer was drained into a distillation flask. The extraction was repeated twice and funnel washed with three separate $10 \mathrm{~cm}^{3}$ portions of the solvent to remove the left over oil solution added to the distillation flask. Repeated distillation at $80^{\circ} \mathrm{C}$ and $90^{\circ} \mathrm{C}$ on a water-bath was done for 15 and $20 \mathrm{~min}$ respectively. The remaining solvent was removed by air drawn through the flask using vacuum pump for 1 minute. The flask was cooled in a dessicator for about $30 \mathrm{~min}$ and weighed. The total oil/grease is obtained from the following expression.

Total Oil and Grease ( $\left.\mathrm{mgdm}^{-3}\right)$

$$
=\frac{A-B-C \times 1000}{\text { Sample Volume in } \mathrm{cm}^{3}}
$$

Where $\quad A=w t(\mathrm{mg})$ of residue and flask

$B=w t(\mathrm{mg})$ of blank

$\mathrm{C}=\mathrm{wt}(\mathrm{mg})$ of flask with blank minus weight of flask without blank residue
One gramme each of the activated carbons was then agitated with $100 \mathrm{~cm}^{3}$ of the effluent and the quantity of oil and grease adsorbed by each activated carbon was determined as above.

\section{Determination of Dissolved Oxygen (DO)}

Three gramme each of the activated carbons was agitated at fast speed for $1 \mathrm{hr}$ with $300 \mathrm{~cm}^{3}$ of the effluent sample in plastic bottle after the latter was over flown for 2-3 min to remove any trapped air bubbles. $1.0 \mathrm{~cm}^{3}$ of $\mathrm{MnSO}_{4}$ solution was added followed by 1.0 $\mathrm{cm}^{3}$ of a alkaline iodide-azide reagent to remove by-product impurity and stoppered immediately to avoid trapping air. The bottle was inverted several times to allow proper mixing and the $\mathrm{Mn}(\mathrm{OH})_{2}$ precipitate allowed to settle as indicated by clear upper supernatant. Then $1.0 \mathrm{~cm}^{3}$ of $\mathrm{H}_{2} \mathrm{SO}_{4}$ was added, bottle restoppered and mixed with several inversions for complete dissolution. That was the prepared sample. Two hundred $\mathrm{cm}^{3}$ of the prepared sample was titrated with $0.025 \mathrm{M} \mathrm{Na} \mathrm{S}_{2} \mathrm{O}_{3}$ solution to a pale yellow colour and starch indicator added with swirling. A dark blue colour developed and with continued titration, colourless end point was obtained. This procedure was repeated and average titre obtained.

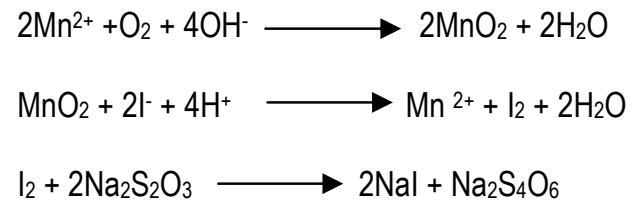

Calculation:

For titration of $200 \mathrm{~cm}^{3}$ sample, $1 \mathrm{~cm}^{3} 0.025 \mathrm{M} \mathrm{Na} 2 \mathrm{~S}_{2} \mathrm{O}_{3}=1 \mathrm{mg} \mathrm{DO}$ per $\mathrm{cm}^{3}$

\section{Determination of Chemical Oxygen Demand (COD)}

Five hundred $\mathrm{cm}^{3}$ of an effluent sample was homogenised for 2 min. Ten $\mathrm{cm}^{3}$ of sample was pipetted into another digestion flask to make the reagent blank and $1.0 \mathrm{~g} \mathrm{H}_{9} \mathrm{SO}_{4}$ (as a catalyst and for removal of any $\mathrm{Cl}^{-}$in sample) and a few glass beads added to each flask. $5.0 \mathrm{~cm}^{3}$ of $0.25 \mathrm{M} \mathrm{K}_{2} \mathrm{Cr}_{2} \mathrm{O}_{7}$ standard solution were pipetted into each flask and whirled to mix. $15.0 \mathrm{~cm}^{3}$ of concentrated $\mathrm{H}_{2} \mathrm{SO}_{4}$ were added slowly to each flask and swirled for thorough mixing. The mixture was refluxed for $2 \mathrm{hr}$ and then cooled to room temperature. Two drops of ferroin indicator were added and titrated with $0.0625 \mathrm{M} \mathrm{Fe}\left(\mathrm{NH}_{4}\right)_{2}\left(\mathrm{SO}_{4}\right)_{2}$ until the colour changed from blue-green to orange-brown. The procedure was repeated twice to obtain average titre of both the sample and the distilled water reagent blank. The next step was the preparation of standard solution: $5.0 \mathrm{~cm}^{3}$ of $0.25 \mathrm{M} \mathrm{K}_{2} \mathrm{Cr}_{2} \mathrm{O}_{7}$ was diluted with 30 $50 \mathrm{~cm}^{3}$ of distilled water and then acidified with $15 \mathrm{~cm}^{3}$ of concentrated $\mathrm{H}_{2} \mathrm{SO}_{4}$.. Two drops of ferroin indicator solution were added to the flask and titrated with $0.0625 \mathrm{M}$ ferrous ammonium sulphate solution. The titres were obtained as explained earlier. 
Five gramme each of the activated carbons were agitated at fast speed for $1 \mathrm{hr}$ with $500 \mathrm{~cm}^{3}$ of effluent sample and the contents allowed to settle and filtered through a sintered glass crucible. The COD $\left(\mathrm{mgdm}^{-3}\right)$ of the filtrate was determined as described above and calculated as follows:

$\operatorname{COD}\left(\mathrm{mgdm}^{-3}\right)=\frac{(A-B) M x 1000}{C}$

Where $\mathrm{A}, \mathrm{B}$ and $\mathrm{C}$ were the $\mathrm{cm}^{3}$ of $\mathrm{Fe}\left(\mathrm{NH}_{4}\right)_{2}\left(\mathrm{SO}_{4}\right)_{2}$ solution used in the titration of reagent blank, prepared sample and standard solution, respectively and $\mathrm{M}$ is the dilution factor.

\section{Determination of Biochemical Oxygen Demand (BOD)}

To determine the BOD, 10, 20, 30, 40 and $50 \mathrm{~cm}^{3}$ of the wellhomogenised effluent sample were pipetted into five separate 300 $\mathrm{cm}^{3} \mathrm{BOD}$ bottles. After adding two shots of nitrification inhibitor to each bottle, distilled water was added to fill each bottle just below the bottle tips, stoppered, inverted several times to mix and then water sealed with distilled water. A plastic overcup was placed over the tip of each bottle and thereafter incubated in the dark for 5 days at $20^{\circ} \mathrm{C}$. The $\mathrm{DO}$ of the 5 -days incubated samples and blank were determined and referred to as $\mathrm{DO}_{5}$. The $\mathrm{BOD}$ is computed as follows:

$\operatorname{COD}\left(\mathrm{mgdm}^{-3}\right)=\mathrm{DO}_{0}-\mathrm{DO}_{5} \times \frac{\text { Volume of BOD bottle }}{\mathrm{cm}^{3} \text { of sample used }}$

$\mathrm{DO}_{0}$ is the pre-incubation $\mathrm{DO}$. Fresh effluent samples were agitated for $1 \mathrm{hr}$ with each of the different activated carbons and the BOD determined.

\section{Determination of Total Solids (TS)}

Total solids and other solids described hereafter, were determined by the method of Ademoroti (1996).

One hundred $\mathrm{cm}^{3}$ of well mixed effluent sample were placed in a pre-weighed clean and dry aluminum dish and then evaporated to dryness on a steam bath at $103-105^{\circ} \mathrm{C}$. The residue was cooled to room temperature in a desiccator and thereafter dried to constant weight in an oven at $103-105{ }^{\circ} \mathrm{C}$. The weight of residue $\mathrm{W}$ is obtained by difference.

$\mathrm{TS}\left(\mathrm{mgdm}^{-3}\right)=\frac{W \times 1000}{\text { Sample volume in } \mathrm{cm}^{3}(100)}$

One gramme each of the activated carbons was agitated at fast speed for $1 \mathrm{hr}$ with $100 \mathrm{~cm}^{3}$ of the effluent and filtered. The TS of filtrate was determined as described above. The TS adsorbed by each AC equals TS of unadsorbed effluent minus TS of filtrate.

\section{Determination of Suspended Solids (SS)}

A glass fibre filter paper was dried to constant weight at 103-

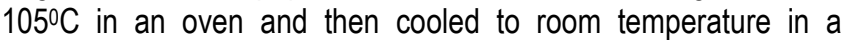
desiccator. The filter paper was weighed and placed in a filter funnel fixed to a filtering flask. One hundred $\mathrm{cm}^{3}$ of well-mixed effluent sample was filtered by vacuum sunction. Both the filter paper and residue were dried to constant weight at $103-105^{\circ} \mathrm{C}$ in an oven to obtain the weight of residues by difference.

$$
\mathrm{SS}\left(\mathrm{mgdm}^{-3}\right)=\frac{S \times 1000}{\text { Sample volume in } \mathrm{cm}^{3}(100)}
$$

One gramme each of the activated carbons was then agitated at fast speed for 1 hour with $100 \mathrm{~cm}^{3}$ of the effluent and then filtered. The SS of the filtrate found and subtracted from the SS of the unadsorbed effluent to determine the adsorbed SS.

\section{Determination of Dissolved Solid (DS)}

Dissolved solid was determined from the relationship below both for the unadsorbed and adsorbed effluent by each activated carbon using $100 \mathrm{~cm}^{3}$ of effluent sample in each case as described for TS and SS above.

$$
\mathrm{DS}=\mathrm{TS}-\mathrm{SS}
$$

\section{RESULTS}

Table 1 shows that the activated carbons are effective in removing the objectionable colours that are often found in molasses. The order of effectiveness falls off as $\mathrm{ZnCl}_{2}$ - activated carbon (AC) > $\mathrm{FeCl}_{3}-\mathrm{Ac}>\mathrm{K}_{2} \mathrm{CO}_{3}-\mathrm{Ac}>\mathrm{CaCl}_{2}-\mathrm{Ac}$. The $\mathrm{ZnCl}_{2}-\mathrm{Ac}$ had the highest adsorption of $92.2 \%$.

Table 2 shows the summarized results of the six adsorbates, dissolved oxygen (DO), chemical oxygen demand (COD), biochemical oxygen demand (BOD), dissolved solids (DS), suspended solids (SS) and total solids (TS). All the test carbons show high tendency for the reduction of the six adsorbates present in the effluent sample. The $\mathrm{FeCl}_{3}$-activated carbon has the highest adsorption affinity for these adsorbates. Apart from the BOD, the $\mathrm{ZnCl}_{2}$-activated carbon had the least adsorption. The order of adsorption was as follows:

$\mathrm{FeCl}_{3}-\mathrm{Ac}>\mathrm{CaCl}_{2}-\mathrm{Ac}>\mathrm{ZnCl}_{2}-\mathrm{Ac}>\mathrm{K}_{2} \mathrm{CO}_{3}-\mathrm{Ac}$.

Table 3 shows the \% adsorption of the two activated carbons aimed at further assessing the extent of adsorption of the two matrices, $\mathrm{FeCl}_{3}-\mathrm{Ac}$ and $\mathrm{CaCl}_{2}-\mathrm{Ac}$, which are consistently more effective than others. Using the following Pearson's coefficient of correlation,

$$
r=\frac{N \sum X Y-\sum X \sum Y}{\sqrt{\left[N \sum X^{2}-\left(\sum X\right)^{2}\right]\left[N \sum Y^{2}-\left(\sum Y\right)^{2}\right]}}
$$


Where:

$\mathrm{N}=$ number of different activated carbons,

$X=$ corresponding concentration of $\mathrm{DO}, \mathrm{COD}$ or $\mathrm{BOD}$ and

$Y=$ values of DS, SS or TS for each activated carbon.

The coefficients obtained are shown in Table 4.

\section{TABLE 4: CORRELATION COEFFICIENTS BETWEEN OXYGEN AND SOLID PARAMETERS ADSORBED BY ACTIVATED CARBONS.}

\begin{tabular}{cc}
\hline Parameters & $\mathrm{R}$ \\
\hline DO and DS, SS or TS & 0.999 \\
COD and DS, SS or TS & 0.907 \\
BOD and DS, SS or TS & 0.762 \\
\hline
\end{tabular}

\section{DISCUSSION}

Results from these studies showed that the four activated carbons can effectively adsorb oils and grease from textile effluents. The order of effectiveness is similar to that of adsorption of molasses. The $\mathrm{ZnCl}_{2}-\mathrm{AC}$ is most effective removing up to $97.4 \%$ of the oil and grease present in the sample therefore using these activated carbons, lives of the aquatic ecology can be preserved longer than anticipated as there would be more diffusion of oxygen into the rivers.

Except for the BOD, the \% adsorptions by $\mathrm{FeCl}_{3}-\mathrm{Ac}$ and $\mathrm{CaCl}_{2}-\mathrm{Ac}$ are generally comparable. They are both ineffective for DO determination in a textile effluent/wastewater but they are very effective for other adsorbates. Their effectiveness in the adsorption of the solids in the effluent shows that $\mathrm{FeCl}_{3}$ and $\mathrm{CaCl}_{2}$ are good coagulants. However, equimolar $\mathrm{FeCl}_{3}$ solution is less viscous than $\mathrm{CaCl}_{2}$ (Gimba 2001) and this might have enhanced better penetration of $\mathrm{FeCl}_{3}$ solution into the carbon matrix during the activation process. Moreover, the ionic size of $\mathrm{Fe}^{3+}(0.064 \mathrm{~nm})$ is less than that of $\mathrm{Ca}^{2+}(0.074 \mathrm{~nm})$ and the result generally suggests that smaller metallic ions of the activating salts are having greater activation power than bigger ones. This could have led to greater adsorptive capacity of activated carbon containing smaller metallic ions for these adsorbates.

In addition, the higher positive charge on $\mathrm{Fe}^{3+}$ aid its coagulating power and enhanced the adsorptive capacity of the carbon activated with $\mathrm{FeCl}_{3}$. It is also worth noting that $\mathrm{Fe}^{3+}$ is a transition metal ion with incompletely filled d-orbitals that can accept electrons from any donor such as the adsorbates form the textile effluent/wastewaters. This would give rise to formation of stable adducts which are coagulated onto the adsorbent.

TABLE 1: PERCENTAGE OF MOLASSES AND OILS/GREASE ADSORBED UNTO 500MM ACTIVATED CARBONS (AC).

\begin{tabular}{llcccc}
\hline \multirow{2}{*}{ Adsorbates } & $\begin{array}{l}\text { Initial concentration } \\
\text { of Adsorbates }\end{array}$ & & \multicolumn{3}{c}{$\%$ Adsorbate Adsorbed } \\
\cline { 3 - 6 } & & $\mathrm{K}_{2} \mathrm{CO}_{3}-\mathrm{AC}$ & $\mathrm{CaCl}_{2}-\mathrm{AC}$ & $\mathrm{FeCl}_{3}-\mathrm{AC}$ & $\mathrm{ZnCl}_{2}-\mathrm{AC}$ \\
\hline Molasses & $100 \%$ (Hazen Units) & 87.4 & 80.9 & 90.7 & 92.2 \\
Oil/Grease & $202.7 \mathrm{mgdm}^{-3}$ & 90.2 & 91.0 & 94.3 & 97.4 \\
\hline
\end{tabular}

TABLE 2: CONCENTRATION OF ADSORBATES ADSORBED UNTO 500MM PARTICLE SIZE ACTIVATED CARBONS (AC).

\begin{tabular}{cccccc}
\hline & $\begin{array}{c}\text { Initial concentration } \\
\text { of Adsorbates } \\
\left(\mathrm{mgdm}^{-3}\right)\end{array}$ & \multicolumn{4}{c}{ Concentration } \\
\cline { 3 - 6 } & 5.2 & $\mathrm{mgdm}^{-3}$ of Adsorbed Adsorbates Adsorbed & \\
\cline { 3 - 6 } & 172 & 1.2 & 2.0 & 2.4 & $\mathrm{~K}_{2} \mathrm{CO}_{3}-\mathrm{AC}$ \\
DO & 5.7 & 3.1 & 121 & 124 & 1.6 \\
COD & 4011 & 3209 & 3611 & 4.1 & 2.7 \\
BOD & 278 & 223 & 250 & 3851 & 3409 \\
DS & 428 & 3432 & 3861 & 267 & 237 \\
SS & & & & 4118 & 3646 \\
TS & & &
\end{tabular}




\section{TABLE 3: PERCENT ADSORPTION OF ADSORBATES UNTO 500MM PARTICLE SIZE FECL 3 -AND CACL2-ACTIVATED CARBONS.}

\begin{tabular}{ccc}
\hline & \multicolumn{2}{c}{$\%$ Adsorbate Adsorbed } \\
\cline { 2 - 3 } Adsorbate & $\mathrm{FeCl}_{3}-\mathrm{Ac}$ & $\mathrm{CaCl}_{2}-\mathrm{Ac}$ \\
\hline DO & 46.2 & 38.5 \\
COD & 72.1 & 69.8 \\
BOD & 71.9 & 54.4 \\
DS & 96.0 & 90.0 \\
SS & 96.0 & 89.9 \\
TS & 96.0 & 92.0 \\
\hline
\end{tabular}

From the results of the correlation shown in Table 4, the order of correlation between the oxygen indices and solid parameters is $\mathrm{DO}>\mathrm{COD}>\mathrm{BOD}$. The relevance of this correlation is to determine the extent to which the adsorbed oxygen parameters can be used to predict or evaluate the amount of any of the solids present in the sample of an industrial effluent. Thus, the quantity of solid that can be adsorbed by an activated carbon, i.e. DS, SS or TS can be evaluated by determination of the oxygen parameters. A high coefficient indicates high solid components of the effluent. It therefore means that the higher the solids the higher the $\mathrm{DO}$ or COD will be. The relatively low value of $r$ between the BOD and solid parameters is in line with the fact that BOD only gives the value of oxygen required to decompose organic matter to simpler forms whereas the COD gives the amount of oxygen required to completely decompose organic matter present in an effluent sample to the final products, $\mathrm{CO}_{2}$ and $\mathrm{H}_{2} \mathrm{O}$. Therefore, $\mathrm{COD}$ should be higher than $B O D$ in any given sample of effluent for the same dosage of activated carbon. BOD measures the amount of impurity by the amount of oxygen required to oxidize it (Shreve \& Brink 1973). The low BOD means low level of impurity as confirmed by the relatively low correlation coefficient in this study.

The activated carbons used in this study are capable of reducing the level of colour present in molasses and amount of oil/grease from a textile effluent. Ninety two and $97.4 \%$ of molasses and oil/grease respectively can be adsorbed onto $500 \mu \mathrm{m}$ particle size of $\mathrm{ZnCl}_{2}$-activated carbon at room temperature.

Out of the four activated carbons, $\left(\mathrm{FeCl}_{3}-\mathrm{Ac}, \mathrm{CaCl}_{2}-\mathrm{Ac}, \mathrm{ZnCl}_{2}-\mathrm{Ac}\right.$ and $\mathrm{K}_{2} \mathrm{CO}_{3}-\mathrm{Ac}$,) the $\mathrm{FeCl}_{3}-\mathrm{Ac}$ is most effective in adsorbing the dissolved oxygen, chemical oxygen demand, biochemical oxygen demand, dissolved, suspended and total solid present in a sample of a textile effluent. The $\mathrm{FeCl}_{3}-\mathrm{Ac}$ is more effective in adsorbing the solid impurities than the oxygen demands but least effective in adsorbing dissolved oxygen. There is a high correlation coefficient between the oxygen parameters and solids present in the effluent. This shows that the greater the amount of solids in an effluent the more the amount of oxygen required for biochemical and chemical processes.

\section{REFERENCES:}

Ademoroti, C. M. A. 1996. Standard Methods for Water and Effluent Analysis. Foludex Press Ltd., Ibadan, Nigeria

Gimba, C. E. 2001. Preparation and adsorption characteristics of activated carbon from coconut shell. Ph.D Thesis Ahmadu Bello University Zaria, Nigeria.

Hardman, J. 1992. More than just a dry drupe", Chemistry in Britain 45, 711-714.

Hassler, J. W. 1974. Purification with activated carbon, Chemical Publishing Co., New York

Houghton, F.R \& Wildman, J. 1971. Manufacture and use of active carbon, Chemical and Process Engineering:1-4.

Lyman, W. J. 1978. Application of carbon Adsorption to the Treatment of Hazardous Industrial Wastes. In Carbon Adsorption Handbook, P.N. Cheremisinoff \& F. Ellerbusch (Eds), Ann, Arbor Science, Arbor, Michigan.

Mkayula, L. L. \& Matumbo M. A. 1994. Preparation and characterisation of activated carbons from some Tanzanian carbonaceous agro-wastes. Bulletin of Chemical Society of Ethiopia, 8(1):25-33.

Noah, A. 1991. Textile Wastes and Effluents Treatment in the Nigerian Textile Industry. A paper presented at a seminar on Environmental Pollution and Control in the Textile Industry organised by the Nigerian Textile Manufacturers Association (NTMA), Airport Hotel, Ikeja-Lagos.

Pollard, S. J. T.; Thompson F.E \& McConnachie, G. L. 1995. Microporous carbons from Moringo Oleifero husks for water 
purification in less developed countries. Water Resources, 29(1): 337-347.

Shreve, R. N. \& Brink (Jr.), J. A. 1993. Chemical Process Industries, Forth Editor, International Student Edition, New York.
SMEWW, 1992. Standard Methods for the examination of water and wastewater, American Works Association and Water Environmental Federation, 18 ${ }^{\text {th }}$ Edition, 1992. 